\title{
Jamaica National Net-Billing Pilot Program Evaluation
}

\author{
December 2015
}

Elizabeth Doris, Sherry Stout, Kimberly Peterson

National Renewable Energy Laboratory

Greening the Grid provides technical assistance to energy system planners, regulators, and grid operators to overcome challenges associated with integrating variable renewable energy into the grid.

\section{USAID}

Greening the Grid is supported by the U.S. Government's Enhancing Capacity for Low Emission Development Strategies (EC-LEDS) program, which is managed by the U.S. Agency for International Development (USAID) and Department of State with support from the U.S. Department of Energy, U.S. Environmental Protection Agency, U.S. Department of Agriculture and U.S. Forest Service.

Greening the Grid prints on paper that contains recycled content. 


\section{NOTICE}

This manuscript has been authored by employees of the Alliance for Sustainable Energy, LLC ("Alliance") under Contract No. DE-AC36-08GO28308 with the U.S. Department of Energy ("DOE”).

This report was prepared as an account of work sponsored by an agency of the United States government. Neither the United States government nor any agency thereof, nor any of their employees, makes any warranty, express or implied, or assumes any legal liability or responsibility for the accuracy, completeness, or usefulness of any information, apparatus, product, or process disclosed, or represents that its use would not infringe privately owned rights. Reference herein to any specific commercial product, process, or service by trade name, trademark, manufacturer, or otherwise does not necessarily constitute or imply its endorsement, recommendation, or favoring by the United States government or any agency thereof. The views and opinions of authors expressed herein do not necessarily state or reflect those of the United States government or any agency thereof. 


\section{ACKNOWLEDGMENTS}

This work was made possible through and in support of the goals of the U.S. Agency for International Development. The authors recognize the interest and support of Jeff Haeni, Jennifer Leisch, and Suzanne Ebert for project guidance and in-country support. We wish to thank representatives from the Office of Utilities Regulation; Jamaica Public Service Limited; solar installers; Ministry of Science, Technology, Energy and Mining; Jamaica Solar Energy Association; National Energy Council; commercial utility customers; Bureau of Standards of Jamaica; and Government Electrical Inspectorate for their time, effort, and interest in providing input through in-person interviews. We are appreciative of comments offered on early drafts from the Meister Consultants Group, in particular Wilson Rickerson and Christina Becker-Birk. Finally, we wish to thank our National Renewable Energy Laboratory colleagues for their reviews of the draft report: Andrea Watson, Jenny Heeter, Michael Elchinger, and Michael Coddington. Any remaining errors are the responsibility of the authors. 


\section{LIST OF ACRONYMS}

BSJ

DC

DG

GEI

$\mathrm{Hz}$

IEC

IEEE

IPP

JPS

JSEA

$\mathrm{kW}$

$\mathrm{kWh}$

MSTEM

MW

NREL

OUR

PV

QSTS

RE

SOC

USAID

UL
Bureau of Standards of Jamaica direct current

distributed generation

Government Electrical Inspectorate

hertz

International Electrotechnical Commission Institute of Electrical and Electronics Engineers Independent Power Producer

Jamaica Public Service Company Limited

Jamaica Solar Energy Association

kilowatt

kilowatt-hour

Ministry of Science, Technology, Energy and

Mining

megawatt

National Renewable Energy Laboratory

Office of Utilities Regulation

photovoltaic

quasi-static time series

renewable energy

standard offer contract

United States Agency for International

Development

Underwriters Laboratories 


\section{EXECUTIVE SUMMARY}

In January 2015, the Office of Utilities Regulation in Jamaica requested that the United States Agency for International Development, supported by the National Renewable Energy Laboratory (NREL), assess the effectiveness of the Jamaica Public Service Company Limited's Net-Billing Pilot Program. NREL collected and analyzed data from a wide range of stakeholders, conducted in-country research, and compared program elements to common interconnection practices to form programmatic recommendations for the Jamaica context. This work was presented in June 2015. Clarifying comments were incorporated into this final draft, and further comments are summarized or, if submitted in writing, reprinted in Appendix $\mathrm{C}$ of this report.

NREL finds that the net-billing pilot program has successfully contributed to the support of the emerging solar market in Jamaica with the interconnection of 80 systems under the program for a total of 1.38 megawatts (MW) at the time of original analysis. ${ }^{1}$ To further improve the success of the program, NREL suggests: ${ }^{2}$

1. Separating interconnection and net billing, realigning various agency roles and responsibilities, shortening the timeline for interconnection and permitting, and adopting an expanded approved inverters list

2. Changing the renewable energy size cap for individual systems to further support the programmatic goal of electricity for self-use.

3. Changing the deposit and fee structure for the net billing program to include cost recovery for the investment of investing stakeholders

4. Studying and determining programmatic next steps in advance of when the $2 \%$ (12 MW) net- billing program cap is reached, which includes:

- Establishing clear goals for both net billing and DG in the context of Jamaica's larger renewable energy goals.

- Creating, through amnesty or registration, a full understanding of the current DG

o on the electric grid, for the purpose of longer-term planning

If the Government of Jamaica prioritizes the benefits reaped by increased DG by streamlining programmatic timing and increasing programmatic transparency, it is likely that demand for the net-billing program will increase. To support safe and reliable integration of DG, NREL suggests the development of an integrated resource plan that provides scenario analysis.

\footnotetext{
${ }^{1}$ As of May 26, 2015, 336 applications had been received and 120 systems had been interconnected for a total of 1.4 MW. Because of the time frame in which it was completed, the analysis here-in summarizes data through Jan. 21, 2015.

${ }^{2}$ Full recommendations are summarized in Table 2of this report .
} 


\section{TABLE OF CONTENTS}

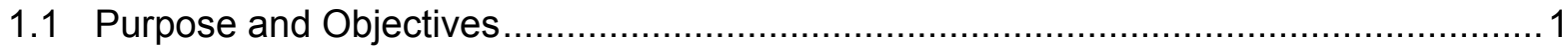

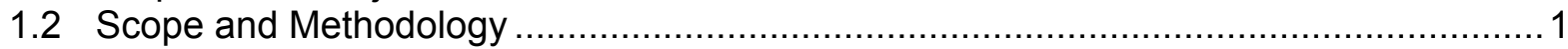

2.1 In-Person Interview Summary and Results.................................................... 3

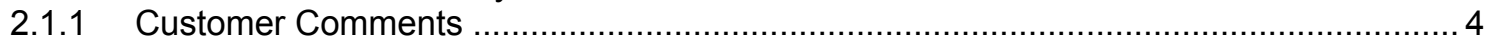

2.1.2 Net-Billing Pilot Program Comments from All Stakeholders ...................................... 5

2.1.3 Technical Comments.....................................................................................

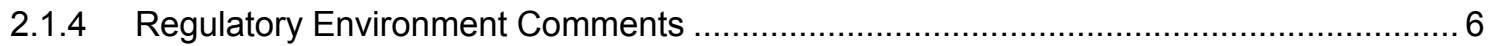

2.1.5 Education and Training Comments .................................................................. 6

2.1.6 Non-categorized Comments.............................................................................

3.1 Practice 1: Increase Transparency by Improving Process ....................................10

3.1.1 Separate Interconnection and Net-Billing Process................................................. 10

3.1.2 Realign Agency Roles ............................................................................... 12

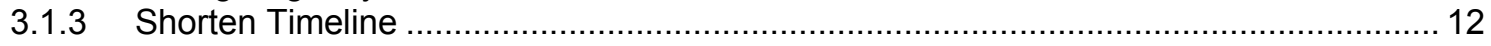

3.1.4 Adopt an Expanded Approved Inverters List........................................................ 15

3.2 Practice 2: Change Renewable Energy Size Cap for Individual Systems .................... 16

3.3 Practice 3: Change Deposit and Fee Structure ...................................................... 16

3.4 Practice 4: Designing the Next Phase of Distributed Generation Policy ....................... 18

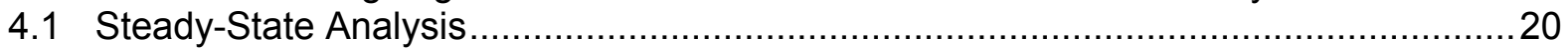

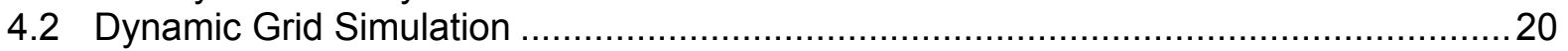

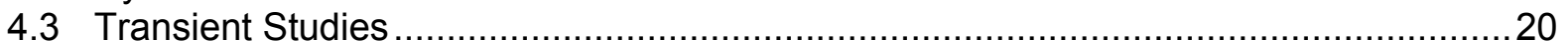

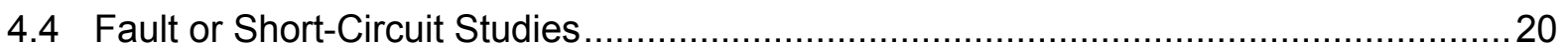

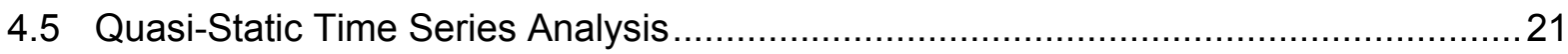

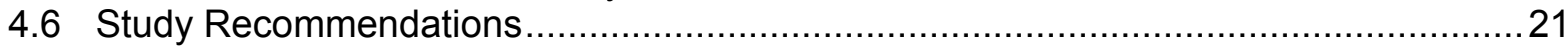

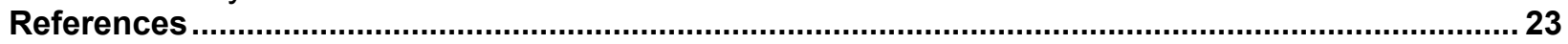

Appendix A. Best Practice Resources for Stakeholders (Annotated Bibliography) ........................25

Appendix B. Summary of Stakeholder Comments on Draft Versions of Report................................2 27

Appendix C. Specific Submitted Written Comments from Stakeholders......................................... 29 


\section{LIST OF FIGURES}

Figure 1: Recommended interconnection process for DG systems .......................... 11

Figure 2: Suggested net-billing flow for a new DG system. ....................................... 15

\section{LIST OF TABLES}

Table 1. Stakeholder Comments on Net Billing and Interconnection ............................ 4

Table 2. Summary of Net-Billing Programmatic Best Practices.................................... 8

Table 3. Customer Paid Fees in Jamaican Net Billing ….......................................... 17 


\section{Introduction}

\section{I.I Purpose and Objectives}

In January 2015, the Office of Utilities Regulation (OUR) in Jamaica requested that the United States Agency for International Development (USAID), supported by the National Renewable Energy Laboratory (NREL), assess the effectiveness of the Jamaica Public Service Company Limited (JPS) Net-Billing Pilot Program. NREL collected and analyzed data from a wide range of stakeholders, conducted in-country research, and compared program elements to common interconnection practices to form programmatic recommendations for the Jamaica context. This evaluation is limited to the net-billing

\section{I.2 Scope and Methodology}

NREL completed a desktop analysis of the program with data provided by OUR, JPS customers, and JPS. The information provided was expanded and confirmed with a site-visit and interviews with a wide variety of stakeholders. These stakeholders included the OUR, customers, JPS, Government Electrical Inspectorate (GEI); Ministry of Science, Technology, Energy and Mining (MSTEM); Bureau of Standards of Jamaica (BSJ);Jamaica Solar Energy Association (JSEA); and the National Energy Council Renewable Energy Sub-Committee. The findings indicate that the program participation is commensurate with other programs of similar structure and duration, with 326 applications filed and 80 systems interconnected during the pilot period (as of Jan. 21, 2015), for a total programmatic capacity of 1.38 megawatts (MW) (approximately $0.15 \%$ of total generation capacity). The initial pilot period was to run from May 2012 through May 2014; however, applications were accepted through May 1, 2015. ${ }^{3}$

Despite different perspectives on the program, broad stakeholder comments followed common themes:

- Complexity, length of time to interconnect, and opaque nature of the interconnection process

\footnotetext{
${ }^{3}$ As of May 26, 2015, 336 applications had been received and 120 systems had been interconnected for a total of 1.4 MW. Because of the time frame in which it was completed, the analysis here-in summarizes data through Jan. 21, 2015.
} 
- Lack of clear interconnection, equipment, inspection and installer standards and codes

- Insufficient GEI staff to handle the volume of system inspections

- Lack of clarity about what happens at the end of the 5-year net-billing period

- Concerns about the renewable energy system size caps of 10 kilowatt (kW) residential and $100 \mathrm{~kW}$ commercial

- Cost and benefit disproportionalities between stakeholder groups

- Equity concerns related to the net-billing rate.

This report summarizes programmatic suggestions that-based on international, U.S., and Caribbean experiences - are designed to further facilitate renewable energy on the Jamaican electricity grid. Suggestions are drawn from these experiences due to the long experience (since the 1980s) and wide variety of net-billing and net-metering structures implemented in a wide variety of states and regions. The suggestions include:

- Separating interconnection and net billing, realigning various agency roles and responsibilities, shortening the timeline for interconnection and permitting, and adopting an expanded approved inverters list

- Changing the renewable energy size cap for individual systems

- Changing the deposit and fee structure for the net-billing program

- Studying and determining programmatic next steps in advance of when the $2 \%$ $(12 \mathrm{MW})$ net-billing program cap is reached such that there is no unexpected gap in programming to support Jamaican policy goals. These actions could include:

- Establishing clear goals for both net billing and distributed generation (DG) in the context of the countries larger renewable energy goals

- Creating, through amnesty or registration, a full understanding of the current DG on the electric grid, for the purpose of longer-term planning.

- The report also describes recommendations for a policy and program environment to support safe, reliable, and cost-effective DG in Jamaica.

Overall, NREL finds the pilot program to have been a key part of successfully developing the DG market (as defined by a growing installer industry and increased DG interconnection relative to prior structure). If the Government of Jamaica prioritizes the benefits reaped by increased DG by streamlining programmatic timing and increasing programmatic transparency, it is likely that demand for the net-billing program will 
increase. To support safe and reliable integration of DG, NREL suggests the development of an integrated resource plan that provides scenario analysis.

\section{Data Analysis and Programmatic Achievements}

The JPS Net-Billing Pilot Program, initiated by the OUR in response to Jamaica's policy goal of having a generation mix of $20 \%$ renewable energy by 2030 , began on May 1 , 2012. Eligible systems included renewable energy systems of up to $10 \mathrm{~kW}$ for residential installations and up to $100 \mathrm{~kW}$ for commercial installations. The program compensated customers for excess energy at the short run avoided cost of generation rate (which is the electricity system's total monthly fuel cost in a given month divided by the net generation in that month) plus $15 \%$ premium. The average avoided cost of generation over the pilot period was $\mathrm{J} \$ 20.3 /$ kilowatt-hour $(\mathrm{kWh})$ or US $\$ 0.18 / \mathrm{kWh}$ (JPS 2014). ${ }^{4}$ The pilot program duration was set at 2 years; however, applications were accepted through May $1,2015 .{ }^{5}$

As of Jan. $21,2015,{ }^{6}$ JPS had received 326 applications for the net-billing program, and 80 of these systems had been successfully interconnected to the grid. As of January 21, 2015, six applications had been suspended and 240 were still listed as in process by JPS. The program received roughly equal numbers of residential and commercial applications. However, the total generating capacity of connected commercial facilities was roughly 10 times that of connected residential facilities $(1.25 \mathrm{MW}$ and $0.12 \mathrm{MW}$ respectively). This difference is due to the larger commercial system sizes (the average system size being $24.6 \mathrm{~kW})$ relative to the residential systems $(4.2-\mathrm{kW}$ average size) as well as a greater number of interconnected commercial customers (51) relative to residential customers (29). There is $1.38 \mathrm{MW}$ of officially net-billed capacity comprising $0.2 \%$ of Jamaica's total generation capacity-well below the programmatic cap of $2 \%$. There is an unknown capacity of interconnected systems that do not participate in the net-billing program.

JPS reported a total program cost of $\mathrm{J} \$ 14,277,726.80$ (approximately US $\$ 125,000$ ) (JPS 2014). This total includes administrative costs, procurement costs, testing, standards documents, and connection and inspection costs. JPS also reported $\mathrm{J} \$ 3,098,442.40$ (approximately US $\$ 26,900$ ) in costs recovered through charges (JPS 2014). These charges, according to JPS, include the direct program cost and meter, ${ }^{7}$ feature key upgrades, and utility disconnect switch payments. JPS reports that this equates to J\$11.2M (approximately US $\$ 97,000$ ) in unrecovered costs to the utility.

\section{I In-Person Interview Summary and Results}

NREL staff completed structured, in-country interviews with multiple stakeholders including six of the 80 net-billing participants. The intention was to be inclusive of a

\footnotetext{
${ }^{4}$ The exchange rate of $\mathrm{J} \$ 114.70$ to US $\$ 1$ (as of $4 / 7 / 2015$ ) is used throughout this report.

${ }^{5}$ Applications received prior to May 1,2015 , will continue to be processed.

${ }^{6}$ As of May 26, 2015, 336 applications had been received and 120 systems had been interconnected for a total of 1.4 MW. Because of the time frame in which it was completed, the analysis here-in summarizes data through Jan. 21, 2015.

${ }^{7}$ Comments on versions of the paper by different stakeholders had conflicting views about whether the utility or the consumer paid for the meter installation.
} 
variety of views, not to be a scientific sampling for the purpose of quantitative evaluation. These stakeholders represented the breadth of the program participants including regulators, policymakers, installers, residential and commercial customers, JSEA, GEI, and BSJ. A summary characterizing stakeholder comments is included in Table 1.

Table 1. Stakeholder Comments on Net Billing and Interconnection

\begin{tabular}{|c|c|c|c|c|c|}
\hline Stakeholder & $\begin{array}{l}\text { Net-Billing Pilot } \\
\text { Program }\end{array}$ & Technical & Regulatory & Education/Training & Other \\
\hline OUR & $\checkmark$ & $\checkmark$ & $\checkmark$ & & $\checkmark$ \\
\hline JPS & $\checkmark$ & $\checkmark$ & $\checkmark$ & & $\checkmark$ \\
\hline BSJ & $\checkmark$ & $\checkmark$ & $\checkmark$ & $\checkmark$ & $\checkmark$ \\
\hline JSEA & $\checkmark$ & & $\checkmark$ & $\checkmark$ & \\
\hline GEI & $\checkmark$ & $\checkmark$ & $\checkmark$ & $\checkmark$ & $\checkmark$ \\
\hline Installers & $\checkmark$ & & $\checkmark$ & & $\checkmark$ \\
\hline $\begin{array}{l}\text { Commercial } \\
\text { Customers }\end{array}$ & $\checkmark$ & & $\checkmark$ & $\checkmark$ & $\checkmark$ \\
\hline
\end{tabular}

Note: Some stakeholders were also residential customers, but were classified by area of greatest involvement in the net-billing program

\section{I.I Customer Comments}

Customers were asked about the process and experience with the entirety of the process of the net-billing program, and their responses spanned both programmatic process and impact on their bills:

- Customers reported a reduction in the cost of their electric bills up to about $30 \%$.

- Commercial customers stated that they were more competitive in their markets due to electricity cost reductions achieved by their solar systems.

- Customers suggested that the program helped Jamaica diversify the nation's energy mix - thus increasing resiliency and reducing dependency on imported fuels.

- Customers with multiple systems noted that the application system improved over the net-billing pilot period.

While questions and responses were focused on the net-billing program, other concerns were revealed by interviewees. NREL categorized the responses as net-billing pilot program, technical, program, regulatory environment, education/training, and noncategorized to aid in the analysis. All responses are aggregated to protect the anonymity of the interviewees and are summarized below. 


\section{I.2 Net-Billing Pilot Program Comments from All Stakeholders}

- Length of interconnection times, as reported by JPS, ranged from 10-18 months. ${ }^{8}$ Reasons cited for the extended timeline include:

- Lack of transparency and standardization in the licensing process

- Lack of direct current (DC) system training for electrical inspectors

- Lack of prior testing of inverters to satisfy BSJ requirements

- The process burden of multiple stakeholder interactions throughout the process and the corresponding soft costs

- Lack of transparency in billing practices between system installation and signing of the standard offer contract (SOC). The time lag is resulting in systems operating prior to JPS approval. Customers suggested that the excess energy should be valued during this time period.

- All interviewed stakeholders suggested that the system size restraints of $10 \mathrm{~kW}$ for residential customers and $100 \mathrm{~kW}$ for commercial customers be reconsidered. There were differing opinions as to how to restructure these limits. Some stakeholders wanted to remove the size constraints or increase the total capacity limits. Other stakeholders suggested limiting the size of interconnected systems to a percentage of normal customer electrical consumption.

- Several stakeholders expressed concern over the deposit equivalent to 3 months of historical billing. These stakeholders believed that this deposit made net-billed renewable energy systems cost-prohibitive to most of the Jamaican population. There is limited transparency for customers as to whether or not the deposit is in fact equally required of all customers. There is also a lack of information on how JPS may use the customer's deposit and the process and time frame for it to be returned.

- Several related concerns about the buy-back rate were discovered. Some stakeholders thought that the avoided cost plus the $15 \%$ premium was too high as it did not account for grid costs while others thought that the rate did not accurately account for the benefits they provided to the grid. Concerns over the accuracy of accounting for the energy sold back to the grid were voiced, as were opinions that net-billing customers should be compensated for the value of the electricity they produced before the SOC went into effect.

- Lack of consistency in quality and service across installations was mentioned as another concern.

- Confusion regarding the licensing and approval protocol for adding capacity to existing systems was highlighted.

- There was concern that increased programmatic costs without corresponding recapture methods would decrease utility profit.

\footnotetext{
${ }^{8}$ Mean reported interconnection time in U.S. jurisdictions range from 60-74 days depending on system size (Ardani et
} al. 2015). 
- Lack of clarity for what happens at the end of the 5-year SOC creates market uncertainty and financial risk for system owners according to some interviewees.

\section{I.3 Technical Comments}

The following technical issues and concerns were expressed:

- The impact of variable renewables on power quality, grid stability, grid security, and increased grid intelligence was mentioned as a concern.

- Several stakeholders cited the lack of completed standardized lists of approved equipment and lack of understanding of the equipment needed to interconnect renewable energy systems with limited negative impacts to the grid.

- Similarly, these same stakeholders noted the technical challenges of finding and properly inspecting grid-tied, non-net-billed systems.

- Safety concerns for utility line workers were also cited.

- Nontechnical transmission and distribution losses and the lack of capital required to address the losses were noted.

- Concerns over large systems (1-2 MW) interconnecting at the distribution level were voiced.

\subsubsection{Regulatory Environment Comments}

The following regulatory issues and concerns were expressed:

- Multiple stakeholders said the lack of an overarching policy for all interconnections to the grid was a concern.

- The lack of separate processes for net billing and interconnection without intent to sell excess generation leaves non-net billed systems in a gray area according to some interviewees.

- A lack of clear overall Jamaican energy goals and policies was cited as creating regulatory uncertainty.

\section{I.5 Education and Training Comments}

The following educational issues were brought up by some of the stakeholders:

- Many stakeholders expressed the need for consumer education campaigns to support the net-billing program and for better education for system owners to understand their photovoltaic (PV) systems' production and functionality.

- Standardized training for installers and DC training for inspectors was requested. 


\section{I.6 Non-categorized Comments}

The following stakeholder comments did not correspond to the above categories:

- Timeliness and consistency in the inspection process for installed systems was cited.

- Grid defection by large electricity consumers was mentioned.

- Quality of installation, service and supply chain of products for the Jamaican market was highlighted as a constraint.

\section{Aligning the Net-Billing Program with Best Practices}

Jamaica's National Energy Plan $2009-2030$ calls for $20 \%$ of the country's energy mix to be supplied by renewables by 2030 , but does not specify the mix of renewable energy technologies or set targets for utility-scale and distributed projects. NREL research finds that some form of valuation of excess energy sold to the grid (e.g., net billing) and interconnection policies are foundational market enabling policies for U.S. states to support solar PV markets and increase the effectiveness of subsequent market development policies (Krasko and Doris 2012).

In-country interviews with stakeholders revealed that the perceived goals of the netbilling pilot program included:

- Facilitating renewable energy on the grid

- Increasing democratization of power such that Jamaicans could produce their own, reduced cost, energy for personal use

- Contributing to a safe and reliable grid

- Increased energy security through decreased fuel imports.

Further clarification on the degree to which the government prioritizes distributed renewable energy over larger-scale renewable energy is necessary to optimize policy, regulatory, and program design. For the purpose of this review, the assumption is that the government prioritizes as much DG as can be safely and equitably (for the people of Jamaica) integrated into the electricity grid. 
This section provides an overview of programmatic opportunities to meet the stated goals. Recommendations are summarized in Table 2.

Table 2. Summary of Net-Billing Programmatic Best Practices

\begin{tabular}{|c|c|c|c|c|}
\hline Recommend & Current Practice & Best Practice & NREL Suggestion & Expected Impact \\
\hline $\begin{array}{l}\text { Increase } \\
\text { Transparency by } \\
\text { Improving } \\
\text { Process }\end{array}$ & 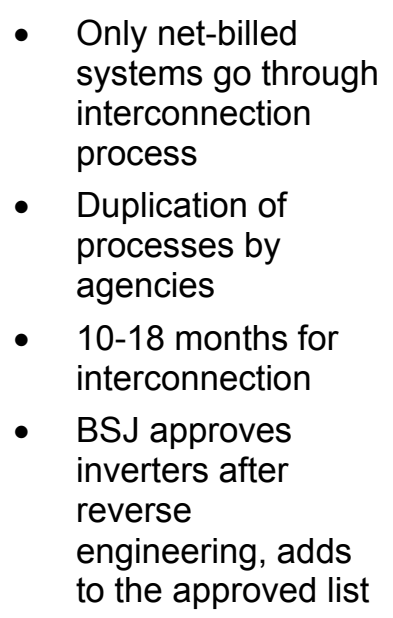 & $\begin{array}{l}\text { Established interconnection and } \\
\text { net- metering (net-billing) } \\
\text { processes: } \\
\text { - Separate interconnection } \\
\text { process from net- } \\
\text { billing/metering mechanism } \\
\text { - Utility handles interconnection } \\
\text { and net billing } \\
\text { - } 3-5 \text { months for interconnection } \\
\text { - Inverters meet UL standards or } \\
\text { IEEE standards (but this is for } \\
60 \mathrm{~Hz} \text { grids) }\end{array}$ & $\begin{array}{l}\text { Establish clear interconnection } \\
\text { guidelines for all systems and } \\
\text { clear net-billing program rules: } \\
\text { - Eliminate duplication of } \\
\text { efforts by realigning } \\
\text { agency roles and } \\
\text { responsibilities } \\
\text { - Establish and enforce } \\
\text { timelines for all phases of } \\
\text { process } \\
\text { - Adopt Australian list or IEC } \\
62109 \text { for inverters built for } \\
\text { Jamaican grid voltage and } \\
\text { frequency }\end{array}$ & $\begin{array}{l}\text { More systems } \\
\text { interconnecting to grid: } \\
\text { - More accurate } \\
\text { cataloging of } \\
\text { systems for JPS } \\
\text { planning } \\
\text { - Less burdensome } \\
\text { process for solar } \\
\text { customers }\end{array}$ \\
\hline $\begin{array}{l}\text { Change RE } \\
\text { System Size Cap }\end{array}$ & $\begin{array}{l}10 \mathrm{~kW} \text { for residential } \\
100 \mathrm{~kW} \text { for commercial }\end{array}$ & $\begin{array}{l}\text { Sizing based on known load. } \\
\text { Usually based on historical data (4- } \\
12 \text { months) }\end{array}$ & $\begin{array}{l}\text { Set size cap to meet } 120 \% \text { of } \\
\text { average } 12 \text {-month historic } \\
\text { annual kWh usage of } \\
\text { customer as determined by } \\
\text { electricity bill and solar }{ }^{10}\end{array}$ & $\begin{array}{l}\text { - } \\
\text { Inssures self-use } \\
\text { predictability of } \\
\text { load and } \\
\text { generation needs }\end{array}$ \\
\hline $\begin{array}{l}\text { Change Deposit } \\
\text { and Fee } \\
\text { Structure }\end{array}$ & $\begin{array}{l}\text { 3-month-equivalent } \\
\text { deposit-if used by } \\
\text { JPS; customer } \\
\text { must replenish with }\end{array}$ & $\begin{array}{l}\text { Deposits vary across utilities. } \\
\text { One example is a US } \$ 250 \\
\text { residential deposit that is } \\
\text { refunded if customers complete } \\
\text { their applications within } 365\end{array}$ & $\begin{array}{l}\text { Reduce or eliminate the } \\
\text { additional deposit requirement } \\
\text { for interconnected customers, } \\
\text { make it refundable if customer }\end{array}$ & $\begin{array}{l}\text { Reducing the cost to } \\
\text { participate will allow } \\
\text { more customers to } \\
\text { install RE systems }\end{array}$ \\
\hline
\end{tabular}

\footnotetext{
${ }^{9}$ Some jurisdictions maintain a set system size cap in addition to the load-based cap. However, the best practice does not restrict overall size caps apart from load-based caps.

${ }^{10}$ Where historic data is not available, loads can be estimated using average Jamaican load per square foot data. See Xcel Energy's Home Usage Estimator in the references for an example.
} 


\begin{tabular}{|c|c|c|c|c|}
\hline Recommend & Current Practice & Best Practice & NREL Suggestion & Expected Impact \\
\hline & $\begin{array}{l}20 \text { days } \\
\text { - Application fee paid } \\
\text { to OUR at } \\
\text { beginning of } \\
\text { process } \\
\text { - JPS pays the cost } \\
\text { of the net billing } \\
\text { meter J } \$ 47,192 \\
(U S \$ 410)^{11} \\
\text { - Monthly program } \\
\text { fees }\end{array}$ & $\begin{array}{l}\text { days } \\
\text { - No interconnection fees for } \\
\text { small systems. Interconnection } \\
\text { study fees may be applied to } \\
\text { larger RE systems with higher } \\
\text { levels of penetration. Most } \\
\text { utilities have a cap on what they } \\
\text { can charge } \\
\text { - Customers do not buy meter } \\
\text { - Nondiscriminatory fixed } \\
\text { charges for all ratepayers }\end{array}$ & $\begin{array}{l}\text { adheres to timelines } \\
\text { Waive interconnection fees for } \\
\text { small systems }(<25 \mathrm{~kW}) \text {. } \\
\text { Interconnection study fees for } \\
\text { larger systems can } \\
\text { compensate the utility for } \\
\text { engineering costs }\end{array}$ & \\
\hline $\begin{array}{l}\text { Designing Next- } \\
\text { Phase } \\
\text { DGPolicy }\end{array}$ & $\begin{array}{l}\text { - Pilot program } \\
\text { ended in May 2014, } \\
\text { but utility continued } \\
\text { to accept } \\
\text { applications } \\
\text { through May } 1, \\
2015 . \\
\text { - Catalogued } \\
\text { systems estimated } \\
\text { at } 0.2 \%, \text { program } \\
\text { cap is } 2 \% \\
\text { - SOC term is } 5 \\
\text { years }\end{array}$ & $\begin{array}{l}\text { - Individual system cap at } 2 \mathrm{MW} \\
\text { or greater } \\
\text { - } \\
\text { Program cap at } 5 \% \text { or unlimited } \\
\text { net-billing, buy-back rate } \\
\text { equivalent to retail rate } \\
\text { - } \\
\mathrm{SOC}=20 \text { years }\end{array}$ & $\begin{array}{l}\text { Inventory grid-connected } \\
\text { systems } \\
\text { - Maintain } 2 \% \text { net-billing } \\
\text { program cap with stage- } \\
\text { gate points for program } \\
\text { review } \\
\text { - Create and publish plan } \\
\text { for program after } 2 \% \text { cap } \\
\text { is met } \\
\text { - Consider SOC period } \\
\text { extension } \\
\text { - Training and certification } \\
\text { of installers and inspectors }\end{array}$ & $\begin{array}{l}\text { - JPS will have better } \\
\text { data to forecast } \\
\text { demand } \\
\text { - } \quad \text { Decrease risk for } \\
\text { investors } \\
\text { - } \quad \text { Stronger solar } \\
\text { workforce, higher } \\
\text { quality systems }\end{array}$ \\
\hline
\end{tabular}

\footnotetext{
${ }^{11}$ Comments on versions of the paper by different stakeholders had conflicting views about whether the utility or the consumer paid for the meter installation.
} 


\section{I Practice I: Increase Transparency by Improving Process}

Based on stakeholder comments and the success of other solar net-billing/metering programs, the Jamaican net-billing program could benefit through the implementation of clearer processes, roles, timelines, and financial requirements. Process transparency reduces risk and increases investment likelihood for investors, installers, and solar owners. The following measures can increase transparency in the net-billing program.

\section{I.I Separate Interconnection and Net-Billing Process}

The current interconnection process in Jamaica only applies to net-billing systems. It has been described as "onerous" by multiple stakeholders and requires many interactions between customers, JPS, OUR, MSTEM, GEI, and BSJ. This adds to the numerous unregulated interconnections that may, if continued, lead to grid instability. In order to provide a safe and reliable grid, the stated goal of the JPS and MSTEM, interconnected systems must be catalogued and planned.

In the U.S. solar market, interconnection standards and net-metering/billing standards are separate policies and most of the actions are incumbent upon the electric utility to both interconnect solar customers to the grid and to activate net-metering arrangements. A "permission to operate" notification is required before DG customers can energize their installed systems and start producing power. The permission is granted after inspection by the local authority having jurisdiction-GEI, in Jamaica-and the utility to make sure all codes have been adhered to and the system is safe to operate. Many utilities have an online application process for interconnection and net billing to streamline the paperwork, keep track of where applications are in the system, and to ensure completion of all forms.

NREL recommends both a separation of the interconnection and net billing; and a realignment of the roles of the various parties to increase efficiency, provide transparency to customers, and to allow for cost recovery by the agencies incurring the programmatic costs. NREL also recommends establishing clear and streamlined interconnection guidelines and processes for systems up to $2 \mathrm{MW}$ on the Jamaican grid to allow for a clearer understanding of power flow on the grid and increase safety and reliability. Applications for larger systems can be reviewed by the utility on a case-bycase basis. For transparency, these processes, roles, and expected timelines could be posted on the JPS website.

Figure 1 shows the recommended interconnection process for DG systems. 


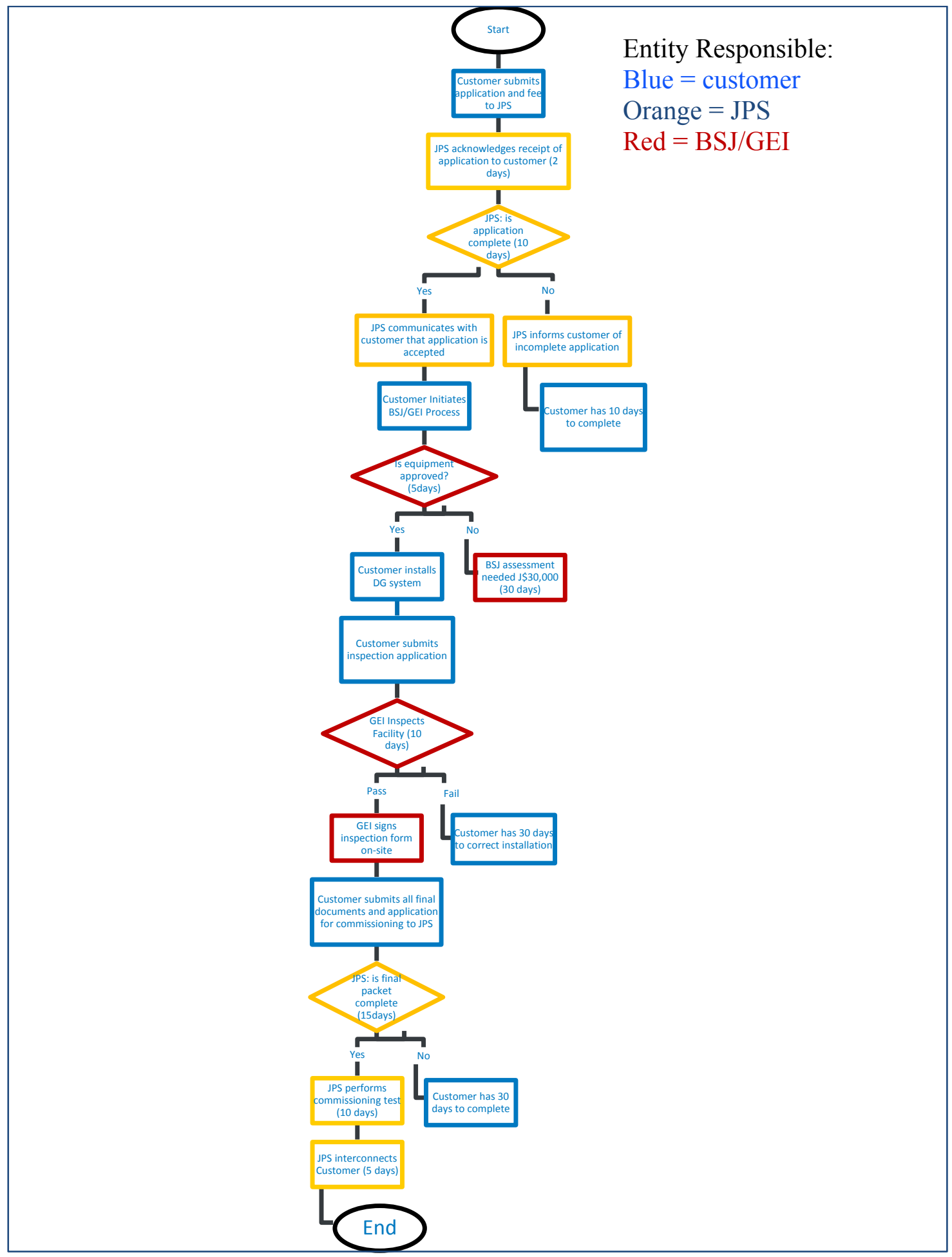

Figure 1: Recommended interconnection process for DG systems. The licensing requirement, which may be integrated into Jamaica's regulatory requirements, is omitted in this recommended process flow for interconnections to streamline the interconnection process and align with international best practices. As interconnected but non-net-billed customers will not sell excess energy to the grid, they should not be considered independent power producers (IPP's) and should not require a license from MSTEM to operate. 


\section{I.2 Realign Agency Roles}

NREL suggests realigning agency roles to avoid duplication of processes and shorten the timeline. Specific suggestions include:

- Positioning OUR and MSTEM as the strategic direction setting agencies for the program, including setting achievable and enforceable timelines for interconnecting systems, establishing appropriate allocation of program costs and benefits, reviewing overall program caps, and serving as arbitrators of disputes between the utility and solar customers. The current structure of the OUR requires OUR's involvement in the process as a licensing agent. Aligning Jamaica's policy with international and regional best practices would indicate the removal of this requirement and shift the regulatory role to a strategic, overarching one.

- Positioning JPS, BSJ, and GEI to implement the program including the integration of cost-recovery mechanisms to accurately allocate costs. Implementation activities include (but are not limited to) receiving and processing applications; approving and inspecting equipment and installations; performing system interconnection; processing the SOC; and accurately net-billing excess energy.

These roles are common practice-regulatory and legislative bodies set overarching goals and policy direction while utilities and jurisdictions having authority ${ }^{12}$ are positioned to implement the program.

\section{I.3 Shorten Timeline}

Another suggested improvement is to shorten the timeline for each step. Figure 2 shows the recommended net-billing flow for a new (i.e., not already interconnected) solar system. This includes setting target maximum times for each step of the process. These time requirements are for all parties involved including the utility, the inspectors, and the customer. Enforcement of utility compliance with these timelines can vary across jurisdictions. For example, in California the Public Utility Commission can mandate process changes or levy penalties on noncompliant utilities. In Massachusetts, utilities can face penalties up to twice the amount of interconnection fees collected in a year (Ardani et al. 2015). The time limits on the steps in the flowchart in Figure 1 are based on average connection times and common practices among utilities.

Commonly, effective practices for net-billing programs internationally indicate that prior to installation of the system, the customer submits a single, complete application and application fee to the utility. The utility may also consider requiring a deposit from the customer that, upon successful interconnection, will be either refunded or applied to future bills. In the recommended process flow, the utility informs the customer of the receipt of the application within two business days and reviews the application for completeness within 10 business days. Incomplete applications are returned to the customer, who has 10 days to complete and refile the application. The utility uses the 10-day review period to determine if a study is needed to safely interconnect the

\footnotetext{
12 In the U.S. market, "jurisdictions having authority" refers to the local government who oversees the permitting and some of the inspection process for installing renewable energy systems.
} 
system. ${ }^{13}$ If it is determined that a study is needed, the customer is informed of the study justification, timeline, and possible costs. Upon completion of the study, the customer is informed of any cost-incurring actions in order to move forward with the application. If the customer chooses to abandon the project due to the results of the study, the application fee is refunded. Once an application has been accepted, the utility informs the customer that construction may begin. The utility also begins the process of replacing the existing meter with a net-billing capable meter and conducting any necessary distribution upgrades. Note that for interconnected but not net-billed customers, the net billing functions will be switched off by the utility. Also, to ensure accurate applications, any installations with capacities greater than $+/-10 \%$ of the capacity for which the application was made will have to submit a new application, and will forfeit fees and deposits associated with the incorrect application.

Customers should acquire inspection applications when they begin installation as well as submit their intended component information to BSJ. BSJ will then have 5 days to inform customers whether or not the intended components are on the approved list. If their intended system components are not on the BSJ approved list, they should submit full product specifications to BSJ for approval. It is important to note that using nonpreapproved components will add up to 30 days to the process.

Upon successful installation of the DG system, the customer will submit the GEI application for inspection including all system and facility drawings. The GEI will then have 10 business days to complete the site inspection. ${ }^{14}$ If the DG system fails inspection, customers will have 30 days to make corrections and resubmit the application for inspection. GEI will then re-inspect the system. GEI will sign letters of completed inspection on-site.

Customers will then submit their final application packets to JPS. This packet will include the final system drawings, the signed inspection letter, insurance documents (if applicable), specification sheets on system components, BSJ reports on nonpreapproved equipment (if applicable), interconnection agreement, and application for commissioning. The utility will then have 15 business days to review the application. If the application is incomplete, it will be sent back to the customer. The customer will then have 30 days to complete the packet. Upon acceptance of the application packet, JPS will have 10 business days to complete the commissioning test. Within 5 days of the successful commissioning test, the customer will be interconnected and the system may be energized.

The timeline above equates to a maximum 57 days from application submission until system interconnection. It should be noted that any incomplete application or unapproved installation will incur greater time in the process. It should also be noted that some of these processes may be done in parallel-thus shortening the length of time to interconnection.

\footnotetext{
${ }^{13}$ Screen limits should be set under which systems can automatically be assessed to determine the need for an indepth system study. It is recommended that these screening criteria be developed following established guidelines, such as the Federal Energy Regulatory Commission's Small Generator Interconnection Procedures, and published to the JPS net-billing website.

${ }^{14}$ This standard time frame could be negotiated with GEI to account for staffing considerations.
} 
For new interconnection customers who wish to participate in the net-billing program, the final application pack to JPS will also include a net-billing application form. The netbilling form will be returned to the customer with the approved application. The customer will then apply for a license to sell electricity back to the grid through MSTEM. MSTEM will grant or deny the license within 10 business days and send copies of the license to both JPS and customer. JPS and the customer will then have 10 days to complete the SOC. Upon the signing of the SOC, JPS will perform the commissioning test and interconnect the customer as described above. It should be noted that customers who elect to interconnect, but not net-bill (that is not sell excess electricity to the grid), will not require licensing through MSTEM as they will not be operating as electricity suppliers. Only customers who elect to net-bill will obtain a license from MSTEM to supply grid power.

Existing interconnection customers can elect to participate in the net-billing program at any time. To do so, they must submit net-billing application forms along with a copy of their interconnection agreements to JPS. JPS will have 15 business days to review the application. The approved application will be sent back to the customer. The customer must apply for the license from MSTEM. MSTEM will have 10 business days to grant or deny the license and send a copy to JPS and the customer. The SOC signing, commissioning test, and interconnection will then proceed as described above.

As illustrated in the sample timeline above, JPS, GEI, and BSJ are the only entities responsible for the implementation of the interconnection program. The process was not designed to remove OUR or MSTEM from the program, but rather to give both entities a strategic role of program design and oversight. As noted above, current policy frameworks in Jamaica make licensing by MSTEM a requirement to sell power back to the grid. As such, MSTEM will continue to have an implementation role in the next iteration of the net-billing program. 


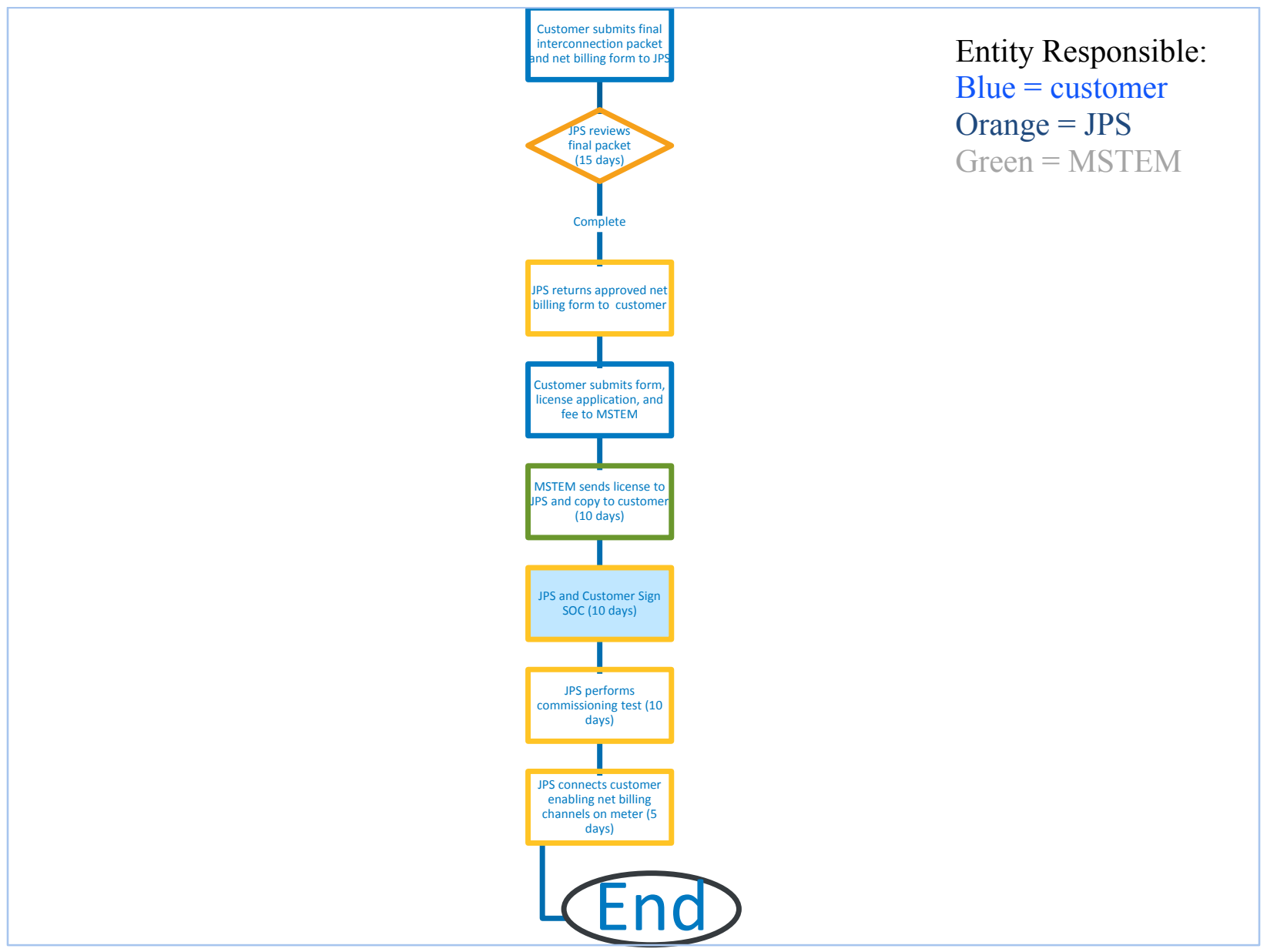

Figure 2: Suggested net-billing flow for a new DG system. The OUR license recommendation is omitted in this recommended process flow for net billing for process streamlining in accordance with international and regional best practices. It is understood that the current policy framework may not allow for this omission, and that a cross-governmental group may be valuable in streamlining the process in accordance with current laws.

\subsubsection{Adopt an Expanded Approved Inverters List}

Another area with the potential to increase transparency and to reduce costs is to expand the approved power converter (inverters list). Customers wishing to interconnect and net bill could be required to use an inverter on the approved list. NREL recommends that Jamaica consider utilizing the Australian Clean Energy Council's list of compliant inverters that is used for that country's renewable energy credit scheme. The list includes grid-connected inverters, off-grid inverters, micro-inverters, multimode inverters, energy + storage inverters, grid control devices, and power conversion equipment; and it is easily searchable online at: http://www.solaraccreditation.com.au/products/inverters/approvedinverters.html\#searchResults.

It also states which components meet the International Electrotechnical Commission (IEC) 62109 standard, which is for the safety of power converters for use in PV systems. This list is suggested because it incorporates many different component types, it denotes which components meet the international standard, it is transparent, and it is 
used by Australia, which has a sub-climate that is tropical and coastal and its grid operates at 50 hertz $(\mathrm{Hz})$; factors applicable to Jamaica's climate and grid.

\subsection{Practice 2: Change Renewable Energy Size Cap for Individual Systems}

The current individual renewable energy system size in Jamaica is limited to $10 \mathrm{~kW}$ for residential and $100 \mathrm{~kW}$ for commercial systems. Some U.S. states in leading solar markets set the allowable system size based on a percentage of the customer's load. For example, an allowable size might be a system that would meet $120 \%$ of a customer's average load over a 12-month period. ${ }^{15}$ This limit ensures that solar customers are not over incentivized to produce solar power that they won't use on-site. In cases where electric vehicle charging is paired with a renewable energy system, these limits are increased, usually by the equivalent of 200-300 kWh per month to allow for charging the vehicle and using the solar energy on-site. In comparison, Puerto Rico sets the system cap at $25 \mathrm{~kW}$ for residential and $5 \mathrm{MW}$ for nonresidential systems in phase 1 of its net-metering program. In phase two, the system caps were set at $15 \mathrm{~kW}$ for residential customers and $100 \mathrm{~kW}$ for commercial customers with the stipulations that customers could only be compensated for up to 1.5 times their monthly consumption. The Dominican Republic's net-metering program limits system sizes to 25 $\mathrm{kW}$ for residential customers and $1 \mathrm{MW}$ for commercial customers.

NREL recommends that individual system size caps for the Jamaica net-billing program be based on $100 \%-120 \%$ of the customer's previous 12-month historic peak load. NREL recognizes that there are differing methodologies for sizing DG systems with varying levels of complexity. However, a system cap as a percentage of customer peak electrical load will ensure that the users of the interconnection and net-billing program are primarily using the generated power for self-use-a stated goal of the program.

\subsection{Practice 3: Change Deposit and Fee Structure}

Utilities may collect application and interconnection fees to recover costs incurred in reviewing and approving DG systems for connecting to the grid. Deposits may also be collected to ensure adherence to interconnection timelines. In Colorado, ${ }^{16}$ the deposit for a residential system is US $\$ 250$ which is refunded if the customer completes their application within 365 days. If it is forfeited, the utility puts the deposit into the state's renewable energy fund. In U.S. states with leading solar markets, interconnection fees are waived or limited to US\$100 for net-metered/billed systems up to $25 \mathrm{~kW}$. Fees may range up to US $\$ 300$ for non-net-metered/billed systems up to $25 \mathrm{~kW}$. Fee structures for larger systems vary and may include inspection fees, study fees, or interconnection fees. Typically fee structures for systems greater than $25 \mathrm{~kW}$ include a fixed charge plus a variable charge based on the system size. In the United States, California law states that solar customers cannot be charged additional fees. Solar customers of

\footnotetext{
${ }^{15}$ For new construction, home load estimate tools may be used in place of historical data. See Xcel Energy's home usage tool in the references for an example.

${ }^{16}$ The Colorado deposit example is taken from Xcel Energy's solar renewable energy credit program.
} 
Austin Energy do not pay extra for their net meters as the utility spreads the cost over all the ratepayers.

Solar customers in Jamaica pay several different fees and a deposit to participate in the net billing program. Table 3 shows these fees. If JPS uses the customer's deposit, the customer is required to replenish it within 20 days.

Table 3. Customer Paid Fees in Jamaican Net Billing

\begin{tabular}{|c|c|c|c|c|}
\hline Description & \multicolumn{2}{|c|}{ Cost J\$ } & \multicolumn{2}{|c|}{ Cost US\$ } \\
\hline Assessment and Approval of Grid Inverters & $\$$ & 30,000 & $\$$ & 261 \\
\hline Deposit - 3 Months Bill & \multicolumn{2}{|c|}{ varies } & \multicolumn{2}{|c|}{ varies } \\
\hline Meter & $\$$ & 57,835 & $\$$ & 503 \\
\hline Insurance & \multicolumn{2}{|c|}{ varies } & \multicolumn{2}{|c|}{ varies } \\
\hline Monthly Direct Program Costs - Residential & $\$$ & 315 & $\$$ & 3 \\
\hline Monthly Direct Program Costs - Commercial & $\$$ & 700 & $\$$ & 6 \\
\hline Application Fee - Residential & $\$$ & 2,000 & $\$$ & 17 \\
\hline Application Fee - Commercial & $\$$ & 10,000 & $\$$ & 87 \\
\hline Infrastructure Changes/Upgrades & \multicolumn{2}{|c|}{ varies } & \multicolumn{2}{|c|}{ varies } \\
\hline Impact Study Cost & \multicolumn{2}{|c|}{ varies } & \multicolumn{2}{|c|}{ varies } \\
\hline Additional Required Property Tax for RE System & \multicolumn{2}{|c|}{ varies } & \multicolumn{2}{|c|}{ varies } \\
\hline Utility Disconnect Switch & $\$$ & 25,000 & $\$$ & 217 \\
\hline Meter Add-ons & $\$$ & 22,093 & $\$$ & 192 \\
\hline Meter Bi-directional Communication & $\$$ & 23,828 & $\$$ & 207 \\
\hline Large Commmercial (over 200VA) ONLY UDS & $\$$ & 200,000 & $\$$ & 1,740 \\
\hline
\end{tabular}

In U.S. best practice solar markets, net-metered customers are not charged additional costs and in some cases are protected from additional charges by law. Fixed charges, akin to Jamaica's monthly program fees, are charged to all customers and vary by state. These fixed charges are used as a cost-recovery mechanism for transmission, distribution, and administrative costs. Other costs for net-metered customers are spread across all ratepayers. One recent study found that at PV penetration levels of $2.5 \%$ or less, customer-sited PV results in roughly equivalent levels of revenue reductions and cost reductions to the utility, thereby having minimal to no impact on non-net-metered customers. At greater penetrations, revenue reductions exceeded cost reductions under existing rate recovery mechanisms (LBNL 2014). Cost recovery for net metering programs is a commonly discussed issue for many states and utilities in the United States. and they are considering various rate designs to equitably allocate such costs. It is difficult, with currently available data, to assess the cost savings to the utility related to reduced fuel purchases due to increased DG. It is recommended that these cost savings be measured and incorporated into total program benefit and cost calculations.

Insurance requirements for renewable energy system owners differ in Jamaica in that homeowners may not carry property insurance. Program requirements for the netbilling program dictate that residential system owners carry liability insurance against 
any damage caused by their renewable energy systems. Best practices in areas in which homeowners insurance is typical dictate the exemption of additional insurance for systems less than $1 \mathrm{MW}$. Further examination of risks and exposure as well as insurance products and costs available can inform these requirements in the next phase of the program.

Given that Jamaica's solar penetration level of net-billed systems is at $0.2 \%$ as of this analysis, costs for participating in the net-billing program could be spread across all ratepayers removing barriers to nascent solar market development. ${ }^{17}$ As penetration levels approach the $2 \%$ net-billing program cap and the costs to nonparticipating customers become appreciable and measurable, cost allocation can be reconsidered. When the amnesty of interconnected systems is evaluated, the program cap may be close to being met. See Recommendation 4 in Appendix B for additional information.

NREL recommends, in accordance with best practices in other jurisdictions, both reducing the additional deposit requirement for renewable energy systems and establishing transparency regarding how the utility implements and repays the deposit. If customer fees are retained, they could be allocated to the entity incurring the costs to allow for cost recovery.

\subsection{Practice 4: Designing the Next Phase of Distributed Generation Policy}

Because of the high, competing electricity costs that have ranged from approximately US\$0.25/kWh to US\$0.37kWh throughout the pilot period, renewable technologies are economically viable with some customers reporting payback periods, without incentives, of 6-8 years. Economic drivers coupled with a further streamlining of the process and counting of uncatalogued systems indicate that total DG on the grid may exceed $2 \%$.

NREL recommends several near-term measures, in addition to Recommendations 1-3 in Appendix B, to improve the net-billing program including implementing better data collection, revisiting the SOC period, and establishing training for installers and inspectors .

The period for the Jamaican SOC is 5 years. Due to high electricity prices in Jamaica, the payback period on PV systems (6-8 years) is shorter than in other markets with lower electricity prices. Correspondingly SOCs range from 15-25 years in markets with feed-in tariffs and are usually 20 years in U.S. net-metering markets. Multiple stakeholders expressed concern over the lack of transparency as to what happens to their net-billing arrangements after the 5-year SOC period is over. Revisiting and extending the contract period may, for the purposes of reducing risk, further support programmatic goals.

Training for solar installers can increase the quality of the solar installations and minimize installation and inspection time. An endorsed installers list could be

\footnotetext{
${ }^{17}$ For more information on how DG impacts all ratepayers, see Financial Impacts of Net-Metered PV on Utilities and Ratepayers: A Scoping Study of Two Prototypical U.S. Utilities in references (Satchwell et al. 2014).
} 
established to ensure quality control. BSJ or JSEA could design and implement a certification or minimum training level for installers to increase JPS's confidence in the quality of the installations. ${ }^{18}$

A mid-term measure to keep solar market momentum going might include examining utility rate designs and crafting policy to send desired market signals. While the National Energy Plan sets overarching goals for renewable energy, policymakers could set clear, long-term goals specifically for solar including the desired amounts for distributed, community-scale and utility-scale systems. Policy and rate designs can then be constructed to achieve these goals and keep momentum going in the solar market. Such rate designs can include implementing a feed-in-tariff, using a value of solar tariff, reallocating fixed and variable charges to ratepayers, changing the net-billing rate, or setting a fixed-compensation rate.

\section{Policy, Program and Technical Environment to Support Safe and Reliable Distributed Generation in Jamaica}

The goal of the recommendations presented is to increase customer access to DG while also ensuring safe, reliable power generation, transmission, and distribution in Jamaica. Regulatory and policy considerations must be balanced with technical concerns to achieve this goal. Recommendations are based on lessons learned and best practices from other jurisdictions as well as considering the Jamaican context. To keep market momentum going, NREL recommends that the OUR lead a stakeholderdriven, integrated resource planning process including studies to understand the costs and benefits of increased DG on the grid.

It is anticipated that making the above programmatic changes will result in a streamlining of access to DG. This streamlined access coupled with the economic viability of DG technologies in Jamaica will lead to an increased capacity of DG. This increase is not without some risk-particularly to the stability of the grid. The currently interconnected renewable energy systems account for less than $1 \%$ of Jamaica's energy generation capacity. At these levels it is difficult to quantify the impacts of DG. However, there are several feeders identified by JPS as having more than $10 \%$ DG, and these feeders could be studied for a better understanding of how DG is affecting the grid. Additionally, the current energy generation mix should be able to accommodate increased levels of variable renewable energy as petroleum generation can be ramped up and down with relative ease.

In order to ensure that the expansion of DG enhances safe and reliable grid operation, NREL suggests the maintenance of the $2 \%$ program cap pending better understanding of increased DG on Jamaica's grid. There are several options for this including steadystate analysis, dynamic grid simulation, transient studies, fault (or short circuit) studies,

\footnotetext{
${ }^{18}$ For example, the North American Board of Certified Energy Practitioners, a nongovernment organization, sets standards for renewable energy professionals in North America.
} 
and quasi-static time series (QSTS) analysis ${ }^{19}$. It should also be noted that these various studies and simulations can be used in concert to create the most robust analysis of a power system.

\section{I Steady-State Analysis}

The first option is to expand on existing grid studies such as the MSTEM-commissioned study, Grid Impact Analysis and Assessment for Increased Penetration of Renewable Energy into the Jamaican Electricity Grid. This study was a steady-state analysis of the Jamaican grid using a plausible renewable energy mix. Siemen's PSS-E Power Transmission System planning tool was used for the study as it was the same software used by JPS. Steady-state studies typically include analysis of load or power flow studies. The MSTEM commissioned study looked at both of these issues. This study could be updated using current renewable energy system data and known planned system data. This would provide an analysis that more closely mirrors Jamaica's actual renewable energy mix.

The goal of a steady-state study is to solve and evaluate power flow operations under worst-case scenarios. This allows utility planners to ensure that there is sufficient generation for loads and losses, voltages at busses are at an acceptable level, generators operate within active and reactive power constraints, and transmission and distribution systems are not overloaded. This is a good first-cut analysis to understand the ability of the grid to absorb renewable energy systems.

\subsection{Dynamic Grid Simulation}

The second option would be to conduct a dynamic grid simulation. Dynamic studies are often used to assess the feasibility of high-penetration levels of variable renewable energy on the grid. Dynamic modeling analyzes components that affect namely the synchronous machine, turbine governor, and exciter system. Dynamic modeling shows whether or not these components will allow a system to remain in synchronism following a major event such as a fault or sudden change in load or generation.

\subsection{Transient Studies}

Transient studies may also be conducted to understand power quality issues such as harmonics and flicker. Transient studies require highly reliable data on generation, loads, and power system characteristics.

\subsection{Fault or Short-Circuit Studies}

Fault, or short-circuit, studies analyze the ability of protective devices to withstand or interrupt short-circuit current. These studies determine the magnitude of current flowing through the system following a fault until steady state is reached. These studies are most often used to set parameters for relay settings and typically consider a variety of fault types including three-phase, phase-to-phase, double-phase-to-ground, and phaseto-ground faults.

\footnotetext{
${ }^{19}$ For more information, please see https://solarhighpen.energy.gov/topics/modeling_and_analysis
} 


\subsection{Quasi-Static Time Series Analysis}

Finally, QSTS analysis can be used to evaluate the operation of a power system. QSTS simulations solve multiple power flow equations at a set, consecutive, discrete time step (ranging from 1 second to 1 hour). It is important to note that the modeled system has to return to an equivalently static (quasi-static) state before the next time series solution can be solved. QSTS is best used for low-bandwidth system components (e.g., line voltage regulators) and is not appropriate for high-bandwidth dynamic behavior modeling. QSTS simulations often include variable-load and generation data from distributed renewable energy systems on the grid. This allows determination of timebased bus voltages and the effects on the system due to generator control mechanisms.

\subsection{Study Recommendations}

Based on stakeholder interviews, the NREL team recommends the following steps to analyze the impact of high DG penetration on the Jamaican grid. First, appropriate stakeholders ${ }^{20}$ should undertake a grid-wide survey of all interconnected systems that are not currently operating under an SOC. During the stakeholder interviews, multiple stakeholders knew of grid-tied renewable energy systems on the grid that had been interconnected with little oversight from the utility. These same stakeholders noted that it was difficult to know exactly how much DG was on the grid. In order to have appropriate inputs into any model, the number, sizes, and locations of these systems must be determined. Without this information, models and simulations will likely not yield useful results.

Upon completion of the grid survey, steady-state analysis can be conducted (or updated from the previous model) to determine possible problematic points on the system. These points should subsequently be studied in greater detail. After steady-state analysis, transient studies should be conducted on the system. Several stakeholders noted power quality concerns with increased DG penetration-these transient studies will determine the extent of any power quality issues. Transient studies should be followed by dynamic simulation to determine any DG impacts on synchronism.

As penetration levels reach and surpass the $2 \%$ threshold, QSTS simulations can be considered. These comprehensive simulations allow detailed analyses of the system including time-depended load and generation changes due to variable renewable energy generation. These models involve significant input data including details on lines, transformers, capacitors, and voltage regulators as well as historical time-series information on loads and renewable energy system output. The more granular the analysis, the more data required. This amount of data also requires significant processing power to run the simulations.

Grid analyses can be obtained from private entities who utilize commercially available software. ${ }^{21}$ NREL can also provide grid analysis support through our Energy Systems Integration Facility - the United States' premier facility for research, development, and

\footnotetext{
${ }^{20} \mathrm{JPS}$ and GEI would be integral to a grid survey, and the participation of OUR and MSTEM would improve integration with longer-term national priorities.

${ }^{21}$ Software options include the free Electric Power Research Institute platform OpenDSS available at:

http://smartgrid.epri.com/SimulationTool.aspx.
} 
demonstration of the components and strategies needed to optimize the entire energy system. NREL can also offer request for proposal design assistance to complete the above analyses.

Finally, all stakeholders discussed the need to review the rate at which customers are compensated for electricity supplied to the grid. There are many ways to evaluate the benefits and costs of DG technologies. Energy, environmental, and ancillary services costs and benefits; generation, transmission, and distribution capacity values; and transmission and distribution loss adjustments are all commonly considered when making this type of rate decision. Other benefits and costs that can be considered include hedging against volatility and enhancing energy mix diversity. To create a longterm, sustainable, and fair DG market, it is recommended that this type of study be conducted by the OUR and MSTEM. ${ }^{22}$

\section{Conclusion}

The JPS Net-Billing Pilot Program has commensurate impact with other programs of similar design and duration. Programmatic complexities, however, combined with favorable economics (6-8 year paybacks) for DG systems may be resulting in uncatalogued interconnections. Streamlining the program design to enable easier interconnection to the grid is likely to result in increased program participation quickly reaching the $2 \%$ program cap and increasing the understanding of DG systems on the grid. Understanding the DG systems interconnected to the grid (with and without net billing) can result in increased planning capacity for JPS to be able to measure progress toward national renewable energy goals.

\footnotetext{
${ }^{22}$ A general framework for this study can be found in Methods for Analyzing the Benefits and Costs of Distributed
} Photovoltaic Generation to the U.S. Electric Utility System listed in the References section (Denholm et al. 2014). 


\section{References}

Ardani, K.; Davidson, C.; Margolis, R.;Nobler, E.(2015). State-Level Comparison of Processes and Timelines for Distributed Photovoltaic Interconnection in the United States. NREL/TP-7A40-63556. Golden, CO: NREL. Accessed April 22, 2015: http://www.nrel.gov/docs/fy15osti/63556.pdf.

Austin Energy, personal communication, 3/3/15.

California Center for Sustainable Energy and The Energy Policy Initiatives Center, University of San Diego School of Law. (2013). Best Practices for Interconnection Processes: Southern California Rooftop Solar Challenge. Accessed March 26, 2015: http://energycenter.org/sites/default/files/docs/nav/policy/research-andreports/Interconnection\%20Process \%20Best\%20Practices.pdf.

California Energy Commission . (undated). FAQs on Net Metering. . Accessed March 26, 2015: http://www.energy.ca.gov/2005publications/CEC-300-2005-012/CEC-300-2005-012-FS.PDF.

Denholm, P.; Margolis, R.; Palmintier, B.; Barrows, C.; Ibanez, E.; Bird, L.; Zuboy, J. (2014). Methods for Analyzing the Benefits and Costs of Distributed Photovoltaic Generation to the U.S. Electric Utility System. NREL/TP-6A20-62447. Golden, CO: NREL. Accessed March 26, 2015: http://www.osti.gov/scitech/servlets/purl/1159357.

Diaz, B.; Meza, E. (2013). "Net metering in Dominican Republic shows results." PV Magazine. Accessed April 7, 2015: http://www.pv-magazine.com/news/details/beitrag/net-metering-in-dominican-republicshows-results- 100011922/\#axzz3Wg2vfC00.

Con Edison. (2015). Distributed Generation Applications and Instructions. Accessed March 26, 2015: http://apps.coned.com/dg/applications/applications.asp.

Emanuel, E.; Alleyne, D.; Phillips, W. (2013). "An assessment of fiscal and regulatory barriers to the deployment of energy efficiency and renewable energy technologies in Grenada." UN ECLAC. Accessed April 7, 2015: http://www.cepal.org/portofspain/noticias/documentosdetrabajo/5/51885/lcarw3.pdf.

"Freeing the Grid 2015: Best Practices in State Net Metering Policies and Interconnection Procedures." (2015). Free the Grid. Accessed March 18, 2015: http://freeingthegrid.org/.

International Renewable Energy Agency (IRENA). (2012).“5.3 Case Study: Grenada."IRENA handbook on renewable energy nationally appropriate mitigation actions (NAMAs) for policy makers and project developers. Accessed April 7, 2015: http://decarboni.se/publications/irena-handbook-renewable-energynationally-appropriate-mitigation-actions-namas-policy-makers-and-project-developers/.

IRENA. (2012). Grenada Renewables Readiness Assessment. Accessed April 7, 2015 https://www.irena.org/DocumentDownloads/Publications/Grenada RRA.pdf.

Jamaica Public Service Company Limited. (2014). Net Billion Pilot Programme Report to OUR.

Krasko, V.A.; Doris, E. (2012). Strategic Sequencing for State Distributed PV Policies: A Quantitative Analysis of Policy Impacts and Interactions. NREL/TP-7A30-56428. Golden, CO: National Renewable Energy Laboratory. Accessed March 26, 2015. http://www.nrel.gov/docs/fy13osti/56428.pdf.

Konold, M. (2013). "Renewable Energy and the Dominican Republic." EarthTechling. Accessed April 7, 2015: http://earthtechling.com/2013/01/renewable-energy-and-the-dominican-republic/.

MSTEM. (2009). Jamaica's National Energy Policy, 2009-2030. Accessed March 26, 2015: http://ocs.mona.uwi.edu/public/conferences/12/schedConfs/11/energyPolicyOctober212009.pdf

New York Department of Public Service, Personal Communication, March 14, 2013. 
Net Metering for Bahamas and Barbados. (2010). Metering.com. Accessed April 7, 2015.

http://www.metering.com/net-metering-for-bahamas-and-barbados/.

Olson, L., et al. (2014). "Renewable Energy Island Index and Marketplace." Presented at the 2014

Caribbean Renewable Energy Forum. Accessed March 26, 2015: http://castalia-

advisors.com/files/2014/CREF-Castalia Index and Marketplace 141007-1.pdf

Pacific Gas and Electric Company (2015a). Distribution Interconnection Handbook. (2015).. Accessed March 26, 2015:

http://www.pge.com/en/mybusiness/services/nonpge/generateownpower/distributedgeneration/interconne ctionhandbook/index.page.

- (2015b). Net Energy Metering. Accessed March 18,

2015: http://www.pge.com/en/mybusiness/services/nonpge/generateownpower/netenergymetering.page

- (2015c). Standard Net Energy Metering (NEMS). Accessed March 26,

2015: http://www.pge.com/en/mybusiness/services/nonpge/generateownpower/netenergymetering/standa rdnem/index.page

"Renewables Interactive Map Country Profile: Dominican Republic." (2015). Renewable Energy Policy Network for the 21st Century. Accessed April 7,

2015. http://www.map.ren21.net/pdf/profilepdf.aspx?idcountry=41.

Sacramento Municipal Utilities District, personal communication, 2/27/15.

Satchwell, A.; Mills, A.; Barbose, G. (2014). Financial Impacts of Net-Metered PV on Utilities and Ratepayers: A Scoping Study of Two Prototypical U.S. Utilities. DOE DE-AC02-05CH11231. Berkeley, CA : Ernest Orland Lawrence Berkeley National Laboratory. Accessed March 26,

2015: http://emp.lbl.gov/sites/all/files/LBNL\%20PV\%20Business\%20Models\%20Report no\%20report\%20 number $\% 20 \% 28$ Sept $\% 2025 \% 20$ revision $\% 29$.pdf.

"Status and Outlook of the Renewable Energies in the Dominican Republic." (2012). Global Workshop on Clean Energy Development: Establishing a Foundation for Low Carbon Energy Systems. Accessed April 7, 2015. http://www.usea.org/sites/default/files/event-

/Dominican\%20Republic\%20Country\%20Presentation 0.pdf.

Sustainable CUNY. (undated). NYS Net Metering FAQ - Residential. Accessed March 18, 2015: http://www.cuny.edu/about/resources/sustainability/solar-america/installer-

resources/ResidentialNYSNetMeteringFAQFinal.pdf.

U.S. Department of Energy. (2015). "Sunshot Initiative High Penetration Solar Portal." Accessed March 20, 2015: https://solarhighpen.energy.gov/.

Virgin Islands Water and Power Authority. (2013). Net Metering. Accessed April 7, 2015: http://www.viwapa.vi/OurEnergyFuture/NetMetering.aspx.

"WAPA Eliminates Requirement for Net Metering." (2013). Virgin Islands Daily News. Accessed April 7, 2015: http://virginislandsdailynews.com/news/wapa-eliminates-requirement-for-net-metering-1.1462067.

Xcel Energy. (undated-a). Minnesota Solar*Rewards® Sample Customer Contract. Accessed March 26, 2015: https://www.xcelenergy.com/staticfiles/xe/Marketing/Files/MN-SR-Contract.pdf.

_ (undated-b). Small Generator Interconnection Agreement. Accessed March 18,

2015: https://www.xcelenergy.com/staticfiles/xe/Marketing/Files/CO-SR-Interconnection-AgreementCustomer-Owned.pdf 


\section{Appendix A. Best Practice Resources for Stakeholders (Annotated Bibliography)}

The following resources may be of interest to the stakeholders designing the next phase of Jamaica's net-billing program and investigating grid integration. Many of the resources are based on the U.S. solar market although contain relevant information for the Jamaican context. While many of these sources reference net metering, they contain relevant information for net-billing program design as well. A further list of curated resources on DG from the $21^{\text {st }}$ Century Power Partnership is available at: http://www.21stcenturypower.org/dglibrary.cfm

\section{Grid Architecture 3.0}

Description: This report, commissioned by the U.S. Department of Energy, outlines the emerging vision of a "smart grid" in the United States. The report is not intended to be a full treatment of reconstructing a modernized grid; rather it outlines the structural challenges of the U.S. current grid and presents some visions of what the next generation electric grid could look like. The document is being used as a resource by New York in its Reforming the Energy Vision Process, which will enable utilities to better plan for distributed energy generation.

Available at: http://www.pnnl.gov/main/publications/external/technical reports/PNNL24044.pdf

Organization(s): U.S. Department of Energy, Pacific Northwest National Laboratory

Methods for Analyzing the Benefits and Costs of Distributed Photovoltaic Generation to the U.S. Electric Utility System

Description: This report examines current and potential future methods, tools and data for capturing the benefits and costs of distributed solar photovoltaics. The focus is on characterizing these costs and benefits from the perspective of an electricity generating utility in the United States. The report is being used by several leading U.S. solar states to inform their calculations "value of solar" cost figures.

Available at: http://www.nrel.gov/docs/fy14osti/62447.pdf

Organization(s): National Renewable Energy Laboratory, Jarett Zuboy

\section{Model Interconnection Procedures}

Description: This guidebook is on its third update and outlines best practices in interconnection procedures in the U.S. solar market. It specifies the various technical requirements, level of review (screens), time frames, and fee processes that have emerged from the Interstate Renewable Energy Council's (IREC's) work with utility representatives, states, and engineers to incorporate renewable energy onto the grid.

Available at: http://www.irecusa.org/wp-content/uploads/2013-IREC-InterconnectionModel-Procedures.pdf

Organization(s): IREC 


\section{Net Metering Model Rules}

Description: This guidebook provides a template for utilities to use when establishing or updating net energy metering rules. The guide is a widely used resource in the U.S. solar market. IREC is an unbiased non-profit organization with over a decade of experience in state regulatory proceedings.

Available at: http://www.irecusa.org/regulatory-reform/net-metering/

Organization(s): IREC

\section{Xcel Energy Home Usage Estimator}

Description: This is an example of a simple home energy usage estimator. This type of estimator can be used to appropriately size DG systems for new homes with no energy consumption history.

Available at: www.xcelenergy.com\%2Fstaticfiles $\% 2 F x e \% 2 F M a r k e t i n g \% 2 F C O-S R-$ 2010-Home-Usage-

Estimator.xIs\&ei=TWo1Vb7vKuTbsATN0oGQDw\&usg=AFQjCNH9AVupH8v91fKOZXn HO9I-AHbKKg\&sig2= tdy53pQ PTqQsda2VvXMw 


\section{Appendix B. Summary of Stakeholder Comments on Draft Versions of Report}

In May 2015, the authors delivered a draft of this report to stakeholders in Jamaica and collected further comments on the recommendations. The review confirmed the core of the recommendations, and comments were offered by a variety of stakeholders on potential implementation strategies. Those comments are catalogued in this appendix. The comments in this appendix were captured in a public meeting, and are therefore attributed to the commenting agency. This summary is not intended to validate the comments, only to catalogue them.

Recommendation 1: Separating interconnection and net billing, realigning various agency roles and responsibilities, shortening the timeline for interconnection and permitting, and adopting an expanded approved inverters list Commenters indicated that the shortening of the timeline is preferable to the current longer system. Jamaica Public Service Company Limited (JPS) noted that due to the on-site inspection necessary to ensure that surrounding infrastructure is technically acceptable for system integration and suggested that a more realistic time was 60 days. The Jamaica Solar Energy Association (JSEA) suggested that in addition to the Australian list for inverters, the European lists also should be considered. JPS representatives suggested and the Office of Utilities Regulation (OUR) agreed to meeting within 2 weeks to develop a schedule to determine next steps for the net-billing pilot program or revised policy. JPS noted that it is developing an integrated resource plan due for delivery in early 2016. Installers also commented that there is a different process for the JPS solar mill product than for other interconnected systems. JPS noted that its inspection (which the recommendation within indicates should be removed) is required because it needs confirmation that surrounding infrastructure can support DG. All stakeholders expressed interest in clear guidelines for the program in terms of programmatic capacity cap.

Recommendation 2: Changing the renewable energy size cap for individual systems to further support the programmatic goal of electricity for self-use JPS and OUR suggested that to maintain programmatic simplicity the residential system cap remain at 10 kilowatts $(\mathrm{kW})$ and the commercial cap be altered to be $120 \%$ of historic use to ensure self-use and be maintained at an upper limit of $100 \mathrm{~kW}$ until the current programmatic cap is met. During the technical training, clarification was sought on historical use. It was suggested by installers that the cap be adjusted to be $120 \%$ of historic annual kilowatt-hour (kWh) usage-a quantity currently tracked through the JPS billing system. JPS noted that a standardized $\mathrm{kWh} /$ square-foot measure would need to be used by both the installers and JPS in order to appropriately size systems. Some installers supported a $150 \%$ cap for commercial to adjust for time-of-use rate usage.

Recommendation 3: Changing the deposit and fee structure for the net-billing program to include cost recovery for the investment of investing stakeholders JPS suggested that a cost-recovery mechanism for investments needs to be clearly outlined in the revision to the policy. Installers argued that the deposit should be removed entirely or reduced after 12 months because net-billing customers represent a reduced financial risk as their payments to JPS are lower. JPS and OUR noted that 
waiving the interconnection fee for smaller (residential) systems may be more common and appropriate for more mature markets and may still be necessary in Jamaica to ensure safe interconnection to the grid.

\section{Recommendation 4: Studying and determining programmatic next steps in advance of when the $2 \%$ (12 MW) net-billing program cap is reached}

This includes:

- Establishing clear goals for both net billing and DG in the context of Jamaica's larger renewable energy goals.

- Creating, through amnesty or registration, a full understanding of the current DG on the electric grid, for the purpose of longer-term planning.

All commenters agreed that a clearly outlined goal for DG could drive a more stable market development for DG in Jamaica. All commenters agreed that the evaluations and next steps should be done prior to the end date of the program to avoid market disruptions. There was a lack of clarity as to whether the $2 \%$ cap referred to all DG or just that connected through the net-billing program, and comments surrounding gaining clarity on that through policy. Installers noted that the Governor of Jamaica had requested that JPS start investing in a more flexible grid and suggested that the next iteration of the net-billing program could be a part of that effort, if planned in concert.

All commenters agreed that the determination of programmatic design for DG, following meeting the $2 \%$ cap on the net-billing program, should be determined in advance of meeting that goal. Installers at the technical training expressed concern that amnesty may not be fully given to customers with un-cataloged photovoltaic systems due to laws surrounding electrical system alterations. They noted that clear definitions of an amnesty (or registration) program would have to be outlined. 


\section{Appendix C. Specific Submitted Written Comments from Stakeholders}

Robert Wright, New Leaf Solar

a. Caps - I think that the hard caps should be increased from $10 \mathrm{~kW}$ to $15 \mathrm{~kW}$ for residential systems to take into account some of the larger houses that exist in Jamaica, especially in Kingston and Montego Bay. Increasing the cap would not preclude smaller residential systems from being installed and especially in resort areas would be more appropriate for some of the second homes and villas that need more capacity than 10 $\mathrm{kW}$. This will support increased competitiveness and help lead to increased investment and employment; all good things. Time of Use analysis should not apply to residential systems.

The commercial systems should have their hard cap increased from $100 \mathrm{~kW}$ to $200 \mathrm{~kW}$. There are thousands of manufacturing and commercial entities that can easily consume the power produced by a $100 \mathrm{~kW}$ system and so a $200 \mathrm{~kW}$ system would be more appropriate. The use of Time of Use data would be encouraged but I would suggest increasing the maximum size to $150 \%$ of the peak consumption to take into account variances in the TOU patterns that exist from customer to customer. Factories that operate at night, for example, will need to export more power during the day to support self consumption, a consensus goal of MSTEM and the OUR.

b. Residential Set Aside - JPS advised that approximately $50 \%$ of the quota under the net billing pilot project had been applied for even though only $0.2 \%$ of the $2 \%$ penetration goal had been fully approved and commissioned. It seems to me that we would want to ensure that the residential stakeholders, critical participants if we want to democratize access to power, should have a specific MW amount set aside for residential installations only; say $4 \mathrm{MW}$. That would mean that the approximately 1000 households would be guaranteed to secure systems using the $4 \mathrm{~kW}$ as the average size of a residential PV installation.

c. Three Months Security Deposit - This should be completely scrapped and only introduced based on credit risk assessment; which is what it was originally intended for. It's completely discriminatory and unfair.

d. JPS Cost Recovery - International precedent should be used to determine what fees JPS should reasonably charge. They should not be allowed to recover the entire cost of their staff and systems investment from net billing customers as much of the investment was required anyway (like upgrades to their legacy IT and Billing systems) they receive commensurate benefits from the program like access to meters that can communicate wirelessly and access to cheap, clean power at a competitive price per kWh; not to mention the goodwill earned and brand halo burnished as a result of their support of clean energy on the island. This project has also allowed them to set up a new profit center, their solar mills and energy efficiency.

e. Overall Net Billing Penetration Goal - Should be increased from $2 \%$ to $5 \%$ and the existing amount will be exhausted soon and it should be a policy imperative to promote distributed solar even more so that utility size solar facilities that benefit a few and have 
to accept the wholesale PPA rate. Distributed solar allows for customers to peak shave and displace expensive power at the retail rate. The target should therefore be increased now in the national interest.

\section{David Barrett, ENBAR Consulting}

THE COMMENTS EXPRESSED ARE THOSE OF THE AUTHOR ONLY AND COINCIDENTALLY MAY OR MAY NOT REPRESENT THE OPINIONS OF ANY OTHER INDIVIDUAL, GROUP OR ORGANISATION. PLEASE BE GUIDED ACCORDINGLY.

General -

1. Very useful overarching document incorporating a number of stakeholder inputs and concerns.

2. Most of the findings are accurate and recommendations for a second phase programme welcomed.

3. Critical to change the report title from the "JPS Net Billing Pilot Programme". With Cabinet approval, MSTEM established the National Net Billing Policy, under legislation/regulations and administered same under the OUR through JPS. This is a National Net Billing Programme.

4. Attach NREL ToR in appendix so readers can determine the limitations placed on the consultants and also independently determine if the objectives were met.

5. Separate the recommendations from the findings (may be a table of the barebones of all recommendations and a table of all findings or executive summary for quick reference). The PPT presentation for example was a useful summary.

6. It was expected that NREL may have made comments/recommendations on the tariff allocated to the net billing programme (short-run avoided cost + premium). What is the international experience? Is the rate acceptable within options for computing the SoC Tariff? Is the rate arbitrary and can it be made more empirical? Etc.?

2.0 pages 7 - critical to note that OUR provided 2 separate start dates in its public determination notice (see JSEA documents provided) when determining the start/end dates. As such the end dates should be accurately stated.

2.0 page 7 - critical to note that since the programme start date the success rate from application to license has been approx $85 \%$ (under control of OUR and MSTEM); success rate from license to SoC and interconnection has been approx $25 \%$ (under control of JPS/GEI/client). In the latter timeline the GEI normally responds within the expected 15 days but applicants have been frustrated by very fluid changes, uncertainties and challenges with the JPS managed stages.

2.0; PAGE 8 - clarify “JPS also reported J\$3,098,442.40 (approximately US $\$ 26,900$ ) in costs recovered through charges (JPS 2014). These charges include the direct program cost and meter, feature key upgrades, and utility disconnect switch payments. JPS reports that this equates to $J \$ 11.2 \mathrm{M}$ (approximately US\$97,000) in unrecovered costs 
to the utility". Please note the applicant pays for the new meter, disconnect switch, facility upgrade etc.

2.1.2 - include;

- Significant bottleneck at stages dealing directly with JPS (85\% success with obtaining license; $25 \%$ success towards final SOC).

- JPS has undue, excessive and inordinate control of process of inspection and approval after license.

2.1.2 - can NREL recommended QF capacities for phase 2?

2.1.2 - was this stakeholder JPS or OUR? (a) "Some stakeholders thought that the avoided cost plus 15\% premium was too high as it did not account for 3 grid costs".... (b) "Confusion regarding the licensing and approval protocol for adding capacity to existing systems was highlighted".(c) "There was concern that increased programmatic costs without corresponding recapture methods would decrease utility profit".

Recommendation - it is critical to separate utility comments from net billing (QF) clients for clarity and that grouped comments correctly represent the constituency groupings as the two constituents (utility or licensees) have diverse goals and expectations for the programme. As stated, the experience as grouped and described could adversely affect the recommendations and outcomes for the QF client experience towards a second phase.

2.1.2 - add comments.

- There needs to be a centralised Governmental repository for Net Billing data (number of licenses; number of SOCs; status of application process, etc.). The MSTEM and OUR are usually not up to date on a daily basis regarding the status of the National GoJ programme and has to request the data of JPS.

- Payment and submission locations should be diversified from the JPS Kingston office only. (JPS has many offices with admin capacity in other parishes).

- Uncertainty of when net billing payments would be made, frequency and form of payment needs to be resolved (some clients have not been paid after 1 year and there are various explanations for when, how and how much they will be actually paid).

2.1.3 - separate utility and OUR comments from utility/net billing clients for clarity and to correctly represent the constituency groupings. How the experience is grouped and described could adversely affect the impression of the client experience for a second phase.

2.1.4 Clarify - "A lack of clear overall Jamaican energy goals and policies was cited as creating regulatory uncertainty." The National Net Billing Policy, RE targets, and programme generation caps are clear. 
2.1.6 - comments;

- Separate utility and OUR comments from utility/net billing clients for clarity so the perspectives correctly represent the constituency groupings. How the experience is grouped and described could adversely affect the client experience for a second phase.

- Require mandatory Quality Performance Standards from utility with sanctions.

- Communication between QF and utility to be formal (written).

- Inadequate, unclear and veiled communication from utility to QF and applicants in particular. Timely communication needed from Utility and Regulator.

- Clarity needed on who has authority in determinations for disputes and processes in the programme - OUR or utility - (OUR refers to JPS and vice versa regarding resolutions of complaints for action by QF/applicants).

- Utility should not burden the programme with information requests from applicant e.g. applicant is required to obtain the utility data from the utility, to give to the utility, to connect to the utility (e.g., pole numbers, transformer information are in the possession of the utility, etc.). Also applicant has to provide line drawing beyond the boundary of their premises and the RE system. Utility has service address and all associated information. These requirements in the application are unnecessary, onerous and should be removed.

- Written report should be required especially from GEI in cases of failed inspection outlining (a) issues and (b) recommendations so QFs can respond quickly and appropriately.

- JPS treats its solar mill clients differentially with shorter inter-connection time and previously with a 2-way digital meter with no export credits. This was not publicised to the market while net billing was being executed in parallel with the JPS stream. Also there is a fair trading issue as the JPS advertises its SolarMill product as "Standard offer Contract Ready" and also that "1 Utility Disconnect Switch" is included in the offer. JPS clients are therefore not subject to the approved and regulated Net Billing Application Process, have lower interconnection equipment costs and also are accelerated in the queue (see attached - http://www.myipsco.com/wp-content/uploads/E-STORE-SOLARMILL.png; dated 1/6/2015).

Table 2 - recommendation - establish quality performance standards with sanctions for utility to meet reasonable timeline and deliverables.

Table 2 - recommendation - set commercial size cap as a fixed number for simplicity. Unable to evaluate the impact of $120 \%$ of average 12 month historic peak load of customer as determined by the electricity bill as acceptable. Perhaps a simple cap of say $200-300 \mathrm{~kW}$ is simpler and adequate for a non-IPP programme.

Table 2 - in Jamaica, the deposit is related to non-payment liabilities. Remove 3 month deposit as the client has reduced the non-payment performance risk to the utility through self generation. 
Table 2 - payment of net billing SR Avoided costs tariff must be clarified in terms of frequency and form.

3.1.1 - accept recommendation - "online application process for interconnection and net billing to streamline the paperwork, keep track of where applications are in the system and to ensure completion of all forms". Excellent.

3.1.1 - accept recommendation - "interconnection standards and net metering/billing standards are separate policies and most of the actions are incumbent upon the electric utility to both interconnect solar customers to the grid and to activate net metering arrangements. A "permission to operate in parallel with the grid" notification is required before DG customers can energize their installed systems and start producing power".

Separations of interconnection and net billing is positive - but also make rules and conditions public instead of the current practice of utility negotiating and approving interconnections on a case by case onsite basis, and with the current accelerated path for its Solar Mill clients.

Proposed process flow recommendations for modification;

- JPS - 7 calendar days for residential application evaluation only (10 days too long). 10 days allowed for commercial QFs in the event that an assessment is required.

- Customer should be permitted to undertake on their own cognizance to initiate Licensed Electrician inspection, GEI and BSJ process in parallel with JPS application at his/her own risk (i.e. it's the customer's risk with low liability or cost to JPS et. al.). This will allow the applicant to shorten the total SoC period.

- CLARIFY - "JPS: Is final packet complete" (15 days).

- Insert start point/execution and duration for SOC process.

- Insert MSTEM/OUR licensing application/approval start/approved and duration.

Figure 1; page 15 - comment on process flow for net billing - accept recommendation "As interconnected but non-net-billed customers will not sell excess energy to the grid, they should not be considered IPP's and should not require a license from MSTEM to operate".

3.1.2 - Clarify - "Positioning JPS, BSJ, and GEI to implement the program including the integration of cost recovery mechanisms to accurately allocate costs". JPS desires to recover costs on items which should be included under normal maintenance and systems which improves their safety and data collection for billing etc.

3.1.3 - Accept recommendation - setting target maximum times for each step of the process. These time requirements are for all parties involved including the utility, the inspectors, and the customer. Enforcement of utility compliance, mandate process changes or levy penalties on non-compliant utilities, penalties apply to GEI, BSJ and Utility. 
3.1.3 - Comment - "If the DG system fails inspection, the customer will have 30 days to make corrections and resubmit the application for inspection. GEI will then re-inspect the system. GEI will sign letters of completed inspection on-site". Written reports should also be required of GEI (or JPS) if DG system (applicant's system) fails inspection.

3.1.3 - is the alternate process flow suggesting a license AFTER the SOC application or is it just the same process flow on another page?

3.1.3 - for simplicity summarise and restate the total timelines for;

- Smooth unimpeded application process (best case scenario). (Total XX days).

- Challenged and impeded application process including applicant fault (worst case scenario). (Total $\mathrm{xx}$ days)

3.1.4 - is considered favourably ("NREL recommends that Jamaica consider utilizing the Australian Clean Energy Council's list of compliant inverters that is used for that country's renewable energy credit scheme") however to avoid limiting the technologies perhaps other proven lists for other jurisdictions could be added?

3.3 - reject - "Given that Jamaica's solar penetration level of net billed systems is at 0.2 percent as of this analysis, costs for participating in the net billing program could be spread across all ratepayers removing barriers to nascent solar market development". The residential sector in particular is antagonistic to further costs regardless of how miniscule and particularly to the sharing of costs with non-beneficiaries. This was already demonstrated and rejected during the JPS Tariff rate review.

\section{3 - table 3;}

- Reject - Deposit Upgrade of 3-Months Bill.

- Reject - or at best share meter cost and meter bi-directional communications. (a) Utility will need to replace/upgrade meters in its normal maintenance operations and was doing so even without the net billing programme (b) utility needs the meter to conduct its normal rate collection activities (c) the new meter with its data and communication features is an advantage to the utility for quality data collection.

- Reject of share utility disconnect switch - required by the utility. RE systems has effective anti-islanding feature. Experience worldwide over time shows this to be a sufficient and highly effective option for safety. Also BSJ should be required to confirm that equipment has anti-islanding feature to satisfy the requirement, therefore mitigating the disconnect switch requirement.

3.4 - recommendation - extended SOC period is very acceptable, but in any case should be no less than $15 \mathrm{yrs}$.

3.4 - accept - "An endorsed installers list could be established to ensure quality control".

4.6 - amnesty has to be created first before investigation of the number of DG interconnected systems to allow free sharing of information without penalty implications. 


\section{Other Recommendations:}

1. STRONGLY AND CLEARLY RECOMMEND GOING FORWARD INTO A SECOND PHASE of no less than 5 years.

2. Recommendations for going forward are integrated in the main report. Clear recommendations ONLY should also be accessible (see recommendation \#1 above) as such a summary should clarify and expand recommendations for going forward. Use either expanded summary, table of recommendations, appendix/annex or executive summary for clarity and brevity.

3. Study should also reference net billing and net metering practices and experiences particularly in SIDs of the Caribbean and other locations (USVI, Bahamas and Barbados referenced in literature but not effectively in the report).

4. Although there may be various interconnection issues of concern to JPS, the Net Billing Programme should be clearly separated from non-net billing interconnection recommendations.

\section{Other:}

Based on the Stakeholders review workshop, it is apparent that JPS wishes to address wider issues of large commercial interconnection, feeder capacity and RE clusters, multiple non-net metering inter-connection processes, potential/future grid stability risks and a forward planning via an IRP or grid stability study. These are however not the prevue of the Net Billing programme and should be separated as the Net Billing Programme in its current state is not a threat/risk. However it may be prudent to proceed to develop parallel processes for interconnection for the $0-100 \mathrm{~kW}$ option for overall addition of new small generation, so small systems can be monitored, be fairly and transparently included and well managed.

The current suspension is therefore unnecessary and the programme should resume while these matters are addressed. 